Irma Rybnikova, Josephine Krüger*

\title{
Between work and non-work: \\ Institutional settings of boundary management in case of German self-employed lawyers**
}

Drawing on the boundary theory (Nippert-Eng, 1996a) and the concept of institutional framework according to Piszczek and Berg (2014), we explore in this paper the link between institutional settings and boundary management practices in the case of selfemployed German lawyers. Qualitative empirical results on the basis of 12 interviews reveal that the institutional context in case of self-employed lawyers combine "discretionary", "bureaucratic" and "greedy" (Nippert-Eng, 1996a) elements which consist of legal requirements, expectations of clients and family-related demands. Ways of dealing with institutional requirements (complying, resisting, and negotiating) in terms of boundary management of self-employed lawyers are discussed.

Key words: work and non-work domains, boundary theory, institutional settings, self-employment (JEL: M12, L84, M54)

* Irma Rybnikova, Academic Assistant, Chair for Organisation Studies, Technische Universität Chemnitz, Thüringer Weg 7, 09126 Chemnitz, Germany.

E-mail: Irma.Rybnikova@wirtschaft.tu-chemnitz.de.

Josephine Krüger, Master of Management and Organization Studies, Technische Universität Chemnitz. E-mail: krueger.josephine@gmx.de.

** Article received: August 4, 2014

Revised version accepted after double blind review: September 1, 2015. 


\section{Introduction}

Boundary theory (Nippert-Eng, 1996a) is the most popular conceptual frame in the research field of work-family conflicts. Drawing on the social-constructivist tradition, this theoretical school regards "work" and "home" not as domains existing in their own way, but mainly as socio-cognitive classification categories, created and used by individuals in order to make the social world meaningful (Nippert-Eng, 1996b, p. 564). One of the most relevant concepts provided by the boundary theory is the idea of "boundary work" which points to strategies and practices used "to create, maintain and modify cultural categories" and to negotiate boundaries between them (NippertEng, 1996a, p. 8). Since boundary theory promises to provide plausible explanations for how employees and their employers manage conflicting work and family requirements by creating, interpreting and negotiating boundaries between those domains, it has been extensively used in empirical studies in the last two decades (e.g. Kreiner, Hollensbe, \& Sheep., 2006, 2009). Despite its wide acceptance in empirical research, there are also critical voices addressing conceptual shortcomings of the boundary theory. In their recent work, Piszczek and Berg (2014) attest current applications of boundary theory a clear tendency towards individualism and see their blind spot in a missing link between boundary work and institutional settings considered. The authors point to the fact that research studies surrounding boundary theory overemphasize individual efforts in creating and negotiating boundaries between work and life, whereas institutional contexts, such as legal regulations, normative institutions or strategic arrangements in the firms have been mainly ignored, both empirically and conceptually (Piszczek \& Berg, 2014, p. 1495).

There is an additional shortcoming of the literature on boundary management between work and non-work domains which potentially hampers an in-depth consideration of institutional settings: Most empirical studies focus on employees of organizations, with boundary working of self-employed persons being addressed in only few studies up to now (e.g. Berke, 2003; Myrie \& Daly, 2009). Additionally, an in-depth consideration of institutional settings framing boundary work of the self-employed is still mainly missed. Having in mind that both domains - work and non-work - stand in case of self-employed persons in a structural conflict, with working time representing billable hours and time for non-work exemplifying income-free time (Rybnikova, Krätzel, \& Schmidt., 2011), it could be assumed that the ways of balancing both domains have sensible economic consequences for self-employed individuals. The ignorance of scholars towards institutional settings while dealing with boundary management in general or in the special case of self-employed persons represents a serious research shortcoming.

In the present study, we follow the call for considering institutional settings of boundary management between work and non-work domains as proposed by Piszczek and Berg (2014). In contrast to Piszczek and Berg (2014), who focus in their study exclusively on traditional employment, we consider boundary work of selfemployed lawyers. Since lawyers have been considered by scholars as a legally highly institutionalized and "demanding" occupation (Kreiner et al., 2009, p. 707), empirical investigation of this occupational group promises a fruitful underpinning of the link 
between the concepts of boundary work and institutional settings. The research question we are dealing with in this study is thus: Which institutional elements are of particular importance for boundary management practices of self-employed lawyers and what kind of dealing with these institutional constrains could be obtained in this occupational group while managing boundaries between work and non-work domains? Consequently, the present study first aims at the mapping of institutional, in particular occupational, settings which shape boundary management practices among selfemployed German lawyers and, second, at exploring the links between institutional settings and boundary work in the group studied. In more general terms, we will analyze to what extent institutional settings in case of self-employed persons constrain individual boundary working or enable it. The study contributes to research literature at least in a twofold way. First, by empirically investigating boundary work of selfemployed lawyers, we expand the sparse applications of boundary theory in the field of freelancers and the self-employed. Second, using the approach of institutional settings inspired by the work of Piszczek and Berg (2014) our study presents one of the first explicit attempts to include institutional factors in explaining individual boundary work and, thus, to apply the institutional perspective beyond traditional employment relationships.

This paper proceeds as follows. First, we give an overview of the boundary theory research and consider in more detail the criticism expressed by Piszczek and Berg (2014) towards it. Second, we focus on literature addressing boundary work of selfemployed individuals and delineate the main institutional settings framing boundary management practices of German self-employed lawyers. Third, we present our empirical approach as well as the results of the study while discussing the linkage between institutional settings and boundary management of self-employed lawyers.

\section{Theoretical background: boundary theory and its criticism}

Even if the boundary theory consists of highly heterogeneous contributions, which can only loosely be considered as representing one theoretical school (Ashforth, Kreiner, \& Fugate, 2000, p. 474), it has become the dominant theoretical frame in the research field of work-non-work conflicts. In most cases, the boundary theory is traced back to the work of Nippert-Eng (1996a, 1996b) who draws on the socialconstructivist paradigm by considering concepts and classifications as a consequence of the socio-cognitive classification and boundary creating of humans trying to make their social world interpretable and meaningful (Nippert-Eng, 1996b, p. 564). The author considers categories of "work" and "home" not as existing for themselves but as a result of numerous socio-cognitive attempts of individuals to create boundaries between both domains. One of the most prominent concepts provided by the boundary theory is "boundary work" which Nippert-Eng describes as consisting of the strategies and practices used to create or to change boundaries between the domains considered (Nippert-Eng, 1996b, p. 564).

Nippert-Eng (1996a, 1996b) describes in her work two ideal tactics how boundary work unfolds, "integration" and "separation", an analytical frame which provides conceptual background for numerous recent studies. "Integration" is described as making no clear distinction between "work" and "home" with "no conceptual bound- 
ary separating their contents and meanings" and "acting in the same way with anyone - boss, co-worker, spouse" (Nippert-Eng, 1996b, pp. 567-568), whereas "segmenting" stands for drawing clear boundaries between both realms, with the result that "home" and "work" represent two mutually exclusive domains (Nippert-Eng, 1996b, p. 568).

One of the main assumptions proposed by Nippert-Eng (1996) and shared by the later scholars of boundary theory, is an agentic understanding of boundary work. By demonstrating in her study that boundaries are mainly individually constructed, with some individuals separating the domains and others trying to integrate both, NippertEng (1996b) emphasizes individual persons as merely subjects of boundary work. The author touches upon the issue of institutional influences solely by considering structural constrains referring to the workplace (1996a, pp. 152-192). Nippert-Eng (1996a) differentiates three forms of workplaces to a different degree allowing for individual autonomy while doing boundary work. There are, first, "discretionary workplaces", referring to workplace arrangements which allow for a high degree of employees' sovereignty regarding their boundary work; second, "bureaucratic workplaces" which are dominated by numerous rules and enable very little individual discretion in how to do personal boundary work, and, finally, "greedy workplaces" which encompass work settings where the employees' life is completely infiltrated by the work (Nippert-Eng, 1996a, pp. 153-157). Nevertheless, the focus on the individual rather outshines a serious consideration of cultural, occupational, organizational or national influences beyond direct workplace.

An insufficient consideration of institutional settings gathered some criticism in the literature, with Piszczek and Berg (2014) providing the most recent of them. The authors state that "the boundary theory in its current form assumes an institutional environment free of much legal regulation" (Piszczek \& Berg, 2014, p. 1508). While arguing in favor of the inclusion of institutional settings into the research around the boundary theory, Piszczek and Berg (2014) focus their analysis on "regulative institutions" as an institutional aspect directly or indirectly affecting boundary work. By drawing on the industrial relations perspective of institutions, the authors define "regulative institutions" as "laws and public policies [which are] related to the interaction of work and family roles" (Piszczek \& Berg, 2014, p. 1495) and which can refer to the local, national or international regulations. Piszczek and Berg (2014) focus in their analysis on the link between regulative institutions and on organizational work practices, with individual preferences for boundary management being of secondary importance and considered by the authors as a result of organizational strategies and regulative institutions which create "a pathway for employees to segment or integrate work and family domains” (Piszczek \& Berg, 2014, p. 1503).

In our study, we particularly focus on individual boundary work as performed by self-employed German lawyers. Our approach is informed by the concept by Piszczek and Berg (2014) as a general perspective allowing for a focus on institutional settings framing individual boundary practices. The main difference to the model developed by Piszczek and Berg (2014) regards the consideration of institutional framework. Following North, who defines institutions as "the humanly devised constraints that shape human interaction" (North, 1990, p. 3), we apply a much broader understanding of institutional settings than "regulative institutions" according to Piszczek and Berg (2014) 
which represent one of many institutional elements potentially influencing individual boundary management strategies. This is of high importance since in the case of selfemployment several usual legal regulations concerning working conditions of employees, such as maximum working hours per week, legal break times, overtime or minimum number of vacation days as considered by Piszczek and Berg (2014) are not valid. Therefore, in contrast to Piszczek and Berg (2014), we do not only consider specific norms and laws which are of relevance for self-employed German lawyers, but also extend our focus towards additional institutional factors which shape working context of the group studied, like socio-economic settings of the self-employment, clients' expectation and family demands.

\section{Boundary work of self-employed persons: previous studies}

Previous empirical studies in the field of work-non-work boundary management have primarily focused on employees in organizations (Kreiner et al., 2006, 2009). Literature on self-employed persons and their individual strategies of boundary management between private and work domains is rather rare. Existing literature mainly addresses either the preferred style of the individual boundary management in terms of segmentation or integration or concrete practices of boundary working among self-employed individuals.

Süß and Sayah (2011) state in their study that the question of the preferred style of boundary management - separation or integration - seems to polarize freelancers, with some of them favoring a clear separation between work and non-work and other freelancers preferring integration, and with both groups explaining their preference as being able to deal more seriously with work as well as with non-work demands (Süß \& Sayah, 2011, p. 263).

Berke (2003), Myrie and Daly (2009) as well as Kreiner with colleagues (2006, 2009) provide exemplary works which do not explore preferences or dominant styles of self-employed, but focus on concrete everyday practices of boundary creation and maintenance. Even though different occupational groups have been studied there, such as Mary Key consultants (Berke, 2003), home-based workers (Myrie \& Daly, 2009) or Episcopal parish priests (Kreiner et al., 2009), the findings show that main practices of boundary management among the self-employed are quite similar and encompass management of time, management of physical space and management of social players (behavioral-social dimension).

Management of time among self-employed encompasses such practices as blocking of specific time periods for work and family (Myrie \& Daly, 2009), controlling work time and finding respite (Kreiner et al., 2009) or using answering machines (Berke, 2003). The spatial management involves any practices of dealing with working and private spaces, such as separating the working area from the private area, restricted access to the office for family members (Berke, 2003), physical distance between work and home (Kreiner et al., 2009) or rules of not being disturbed while at work (Myrie \& Daly, 2009). Management of social players mainly refers to behaviors which maintain the boundaries created through social actors and includes e.g. rules for clients and family members regarding accessibility (Myrie \& Daly, 2009), managing expectations of clients and family members (Kreiner et al., 2009), using other people 
(Kreiner et al., 2009), performing rituals of transition from one domain to another (Myrie \& Daly, 2009) or creating own work- or non-work-related personal identity (Berke, 2003).

\section{Self-employed lawyers in Germany: Institutional settings}

By focusing on self-employed lawyers, we address a group of professionals who are mainly assumed to manage their work in a flexible and autonomous way. In fact, they are exposed to conflicting work demands which can, to a considerable degree, restrict individual boundary management.

Institutional settings of self-employed lawyers in Germany consist of legal and occupational norms, structure of occupation, family demands and clients' expectations since they prescribe numerous occupation-based issues, such as personal accessibility, technical equipment, qualification, costs, pre-specified deadlines, reporting and issues of legal liability. Permanent personal accessibility is expected not only by the clients alone (Lührig, 2013, p. 266) but is also a result of a significant increase in the number of lawyers and a growing competition among them (Hommerich, Kilian, \& Dreske, 2008, p. 31). According to the Federal Lawyers Act (BRAO) ${ }^{1} \$ 53$ lawyers are obliged to the so-called rule of replacement: in case of an absence for a week or longer lawyers have to appoint a representative; if the representative is appointed by the chamber of lawyers and not by the lawyer himself, the latter must bear the costs of the representative (The Federals Lawyers Act (BRAO), $\left.\int 53(9)\right)$. As a result, lawyers not only have to take appropriate organizational or personnel measures in case of absence (Koch \& Kilian, 2007, p. 206) but there is often the necessity for self-employed lawyers to employ staff in order to guarantee accessibility.

The qualification of lawyers represents a second relevant area of institutional settings. Not only clients nourish critical expectations towards the performance of lawyers (Oberlander, Eggert, \& Kreider, 2010b, p. 11). According to the Specialist Lawyer's regulations $(\mathrm{FAO}){ }^{2}$ in order to acquire and to maintain the specialist lawyer title, a certain number of cases dealt with has to be reported within three years - the number of required cases depends on the field of specialization. Even though since 2009 there has been an option for lawyers who worked to a lesser extent due to maternity protection or parental leave to extent the period granted (Wendt, 2012, pp. 110f.), it is often difficult for self-employed lawyers to deliver a sufficient number of cases, since their specialist fields often cover a broad range of subject matters (Wendt, 2012, p. 111). At the same time there are legal prescription regarding advanced training for all lawyers $(\$ 43 \mathrm{a}(6) \mathrm{BRAO})$; for specialized lawyers there is even a sanctioned duty of at least ten hours of yearly training, since "[the] permission to use the title of "Special-

1 German title: Bundesrechtsanwaltsordnung (BRAO) (Source: Bundesrechtsanwaltsordnung (BRAO) in der im Bundesgesetzblatt Teil III, Gliederungsnummer 303-8, veröffentlichten bereinigten Fassung, die durch Artikel 7 des Gesetzes vom 10. Oktober 2013 (BGBl. I S. 3786) geändert worden ist).

2 German title: Fachanwaltsordnung (FAO) (Source: Fachanwaltsordnung (FAO) in der Fassung vom 1.1.2011. Retrieved 01.11.2013, from http://www.brak.de/w/files/02_fuer_anwaelte/berufsrecht/fao-stand-01.01.11.pdf.). 
ized Lawyer" [...] may be revoked in the event of failure to undertake a course of continuing professional development prescribed in the code of conduct for the profession"3 (The Federals Lawyers Act, \$43c (4)).

Costs represent a sensitive topic and a relevant institutional factor for the selfemployed in any occupation. Self-employed lawyers do not receive wages paid in case of sick leave unless they are covered by appropriate private insurances. Consequently, absence from work due to sickness involves a financial burden and a potential loss of customers. Additionally, lawyers in Germany often pursue a secondary job outside their profession ${ }^{4}$, assumingly also for reasons of guaranteeing income, despite of the fact that according to BRAO, $\$ \$ 4-17$, the admission to the occupation can be refused in case of a secondary activity which is not compatible with the lawyer's occupation. Lawyers are obliged to make their contribution to the occupational pension scheme, the local lawyer's association and to the liability insurance. Moreover they have to pay the chamber's membership fee ( $\$ 89$ (2) Sentence 2 BRAO; o.A. 2010, Koch \& Kilian, 2007, pp. 32ff. Rn. 121-127 and p. 26 Rn. 96f.) Further expenses are those for premises, materials and possibly for personnel (Oberlander, Eggert, Nafts, \& Kreider, 2010a, p. 112). Self-employed lawyers with reduced working hours during parental leave do not receive any reduction of required contribution (e.g. chamber's membership fee) despite lower revenues nor do the occupational pension schemes have an obligation to accept periods of parental leave for a pension increase (Prossliner, 2009, pp. 212f.). It leads to significant costs which correspond to a rather less lucrative revenue structure of self-employed lawyers, resulting from the fact that their client structure typically includes private mandates which are often less profitable than commercial mandates and of further low-yield mandates, such as cases of family law, social legislation or legal aid (Kilian, 2011, p. 718).

The client structure in turn determines the lawyers' work context, as for example the pre-specified deadlines, which are particularly short in case of civil law complaints (e.g. \$217 $\mathrm{ZPO}^{5}$ ), leading to a lack of planning and to unforeseen periods of high work intensity.

There are also considerable requirements regarding the formal reporting of lawyers' activities. Lawyers are obliged to provide information and notifications, to submit and to report to the chamber, all requiring an immediate processing (Koch \& Kilian, 2007, pp. 27f. Rn 99-108). Additionally, lawyers are subject to certain infrastructural requirements, for example at least the provision of a telephone connection (Koch \& Kilian, 2007, pp. 52-53).

Furthermore the occupation of a lawyer can be assigned to a high-risk occupational group because of its high standards of liability (Remmertz, 1996, p. 156). All

3 The quote stems from the English version of the legal text.

4 According to Busse (2010, p. 547), in 2004, about 63 per cent of all approved lawyers in Germany less the unknown number of employed lawyers pursued secondary jobs.

5 Code of civil procedure (German title: Zivilprozessordnung (ZPO), Source: Zivilprozessordnung in der Fassung der Bekanntmachung vom 5. Dezember 2005 (BGBl. I S. 3202; 2006 I S. 431; 2007 I S. 1781), die durch Artikel 1 des Gesetzes vom 10. Oktober 2013 (BGBl. I S. 3786) geändert worden ist.) 
self-employed lawyers in a single firm are liable with their private property. Possible liability claims may arise from contractual liability, liability in tort and from third-part liability. Any violation of the requirements mentioned above, such as deadlines or the time period for informing the client, might have liability consequences. In order to avoid liability claims, lawyers have to show a quasi-permanent attendance and a continuous control of all means of communication according to jurisdiction (Römermann \& Hartung, 2002, pp. 176f. Rn. 13).

In the meantime, there has been a range of studies dealing with occupational requirements of lawyers in Germany; however, the particular situation of self-employed lawyers has barely been the object of analysis. Most authors either deal with employed lawyers only or with heterogeneous groups of lawyers where the self-employed represent one of the subgroups considered. Up to now, most attention has been given to two questions: gender differences regarding occupational orientation of lawyers and the main features of lawyers' work, including normative expectations towards performance and institutional demands.

Figure 1: Institutional context of boundary management between non-work and work realms of self-employed lawyers in Germany

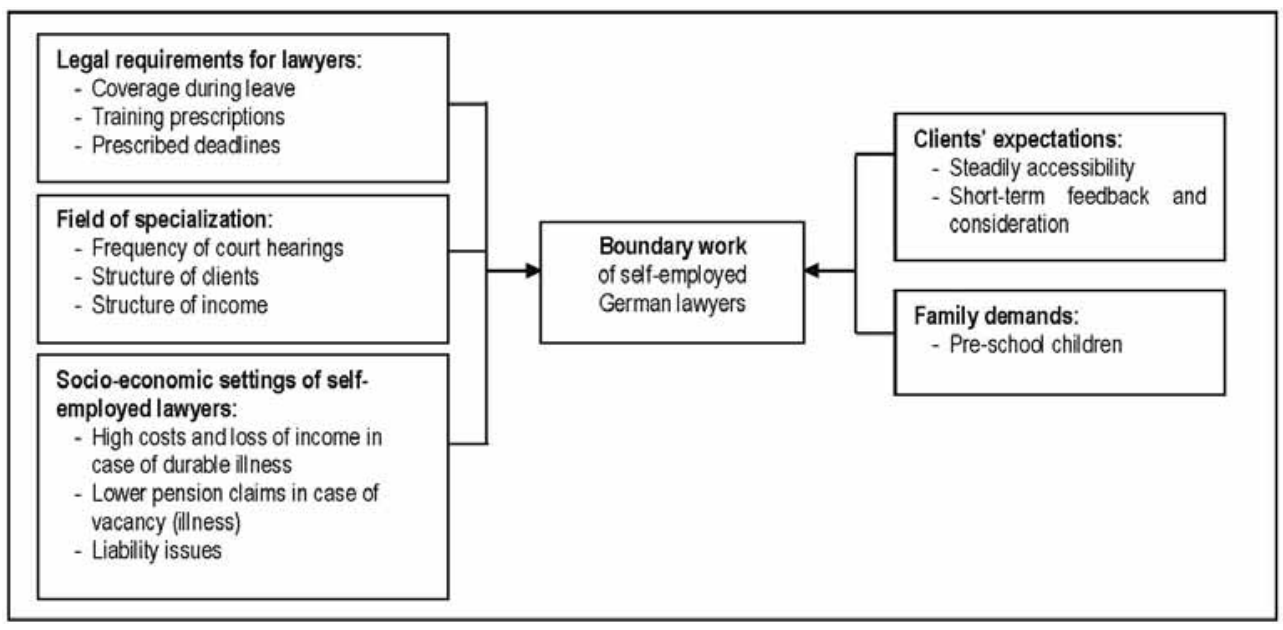

Hommerich observes that both male and female lawyers without children demonstrate a high professional orientation (Hommerich, 1988, p. 108), with only the group of women lawyers with children perceiving acute conflicts between occupational and family orientation and trying to moderate these conflicts by flexible working arrangements, including self-employment (Hommerich, 2001, p. 138). As a result, selfemployed female lawyers with school-aged children tend to have a shorter working time than their female colleagues without children (Hommerich, 2001, p. 138). Plickert and Merkens (2012/2013, p. 93) argue that these results do not have so much to do with self-employment but are influenced by still dominant traditional expectations towards lawyers such as unreserved availability, high presence at the workplace and overtime as indices of high performance. Family-related responsibilities are thus expected to expose lawyers to severe conflicts between work and non-work domains 
(Plickert \& Mertens, 2012/2013, p. 99). Besides the "culture of overtime" with 60 working hours a week (ARGE, 2012, p. 22), unscheduled short-term events and the reluctance of courts to schedule long-term hearings have been perceived by the female lawyers as main impediments to their work-non-work balance (ARGE, 2012, p. 18). Contrary to the assumption that self-employment enables persons to better manage conflicts between home- and work-related requirements, Lühring (2012, p. 226) shows that self-employed female lawyers are burdened particularly hard by their family and work requirements since small firms turn out to be less flexible than large companies.

In short, institutional settings of self-employed lawyers in Germany include different elements, with legal requirements, occupational situation, clients' expectations, requirements referred to self-employment as well as family demands being the most important for boundary work practices, as shown in Figure 1. It could be assumed that this complex institutional field leads to several contradictory requirements and tensions regarding boundary management between work and non-work domains.

\section{Method of the study}

Since studies concerning institutional constraints as well as boundary work of selfemployed lawyers are quite rare, a qualitatively explorative approach was chosen with semi-structured interviews with self-employed lawyers providing the empirical basis of the study.

Interview questions were developed drawing on conceptual considerations as well as on interview questions used in other empirical studies on similar issues (e.g. Kreiner et al., 2009). Three main issues have been addressed in the interviews: a) sociodemographic data such as gender, age, marital status and income, b) everyday working conditions of self-employed lawyers such as questions on work space and place, working hours or the organization of work, c) individual boundary management preferences and strategies.

Participants for the interview were selected according to two criteria. First, potential candidates had to be self-employed for at least one year; second, it was necessary that they generate the dominant part of income from their freelance activities. About 100 persons from Saxony and Thuringia were contacted who match these criteria. The final empirical material is based on 12 individual interviews which were conducted between September and October 2013. Seven interviews were face-to-face, taking place mainly in the offices of the interviewees; five interviews were conducted via telephone. The interviews lasted between 19 and 53 min., on average 34 min.

Six of the persons interviewed are female and six male, on average 43 years old, with the youngest interviewee being 27 years old and the oldest 62 years. Seven interviewees are married, one engaged, one divorced and three single. All but three persons have children, in five cases they have school-aged children, which can be considered as an indication for greater family responsibilities and potentially more acute workfamily conflicts as well as more intense boundary working. All but one interviewed persons worked at the time of the interviews as single lawyers; the remaining one person was then employed with a law firm. In the interview, however, she focused on her past experience as a self-employed lawyer. The experience of being a self-employed lawyer ranges from one year to 22 years, with an average of ten years of self- 
employment. Ten interviewees work in their individual offices, one shares her office with accountants and the remaining one has a sublease agreement with other lawyers.

All interviews except one were recorded and completely transcribed. One participant did not agree to the interview being recorded, thus, the material here is based on notes of the interviewer and the interview minutes. After all personal data in the transcripts were made anonymous, a qualitative content analysis according to Mayring (2010) was used as a method for the analysis of the interviews. All interview transcripts were screened in order to reduce the complete material to the passages explicitly referring to the issues addressed by the research questions. Our qualitative content analysis of the data proceeded in two steps. First, a system of deductive categories regarding boundary work practices was generated while drawing on categories derived from similar empirical studies, such as temporal, spatial and behavioral practices (e.g. Kreiner et al., 2009). Table 1 summarizes the boundary management practices obtained together with selected characteristic quotes from the interviews (Table 1).

Second, we filtered out the most dominant institutional elements, referred to in interview passages on boundary management practices. Here, the categories of the analysis were inductively extracted from the interview material and resulted in the following three main institutional constituents: occupational demands, clients' expectations and family-related or private demands. This step was necessary in order to elaborate how boundary management practices and institutional settings are interlinked. Concretely, all boundary work practices and respective interview quotes were examined to ascertain the institutional elements which they refer to or by which elements of institutional context were they induced.

Both authors were involved in the analysis of the interview material in the form of reflexive task division. It means that ongoing discussions took place before and during the analysis of the interviews. After the main scheme of categorization was proven as intersubjectively plausible for both researchers, the coding work was divided with one researcher categorizing temporal and behavioral practices and the second researcher dealing with spatial practices. This procedure required both researchers to analyze all interviews. The results of this first step of analysis were validated by jointly discussing and re-examining the plausibility of interview codings. The fact that there were several intersections between the categories used, especially between behavioral boundary management practices and the remaining practices, particularly fostered discussions and required reflexive decisions. The fact that both researchers were familiar with the complete interview material made the intersubjective re-examination of analysis possible. The same procedure was repeated in the second step of analysis. Because of the high familiarity with the interview material, researchers jointly developed the first schema of relevant institutional elements and again screened the interviews several times in order to filter out the ways how each institutional element is interlinked with boundary management practices as reported by the interviewees. The final intersubjective discussion of the results led to some adoptions of the categories used. The most important of them was the creation of the main category "occupational requirements", which encompasses legal requirements, aspects resulting from law field specialization and socio-economic issues of self-employment. Since all these elements are highly interlinked and refer to the occupation of lawyers, we decided - in difference to 


\section{Table 1: Practices of boundary management between life and work realms among} German self-employed lawyers

\begin{tabular}{|c|c|c|}
\hline $\begin{array}{l}\text { Practices of boundary } \\
\text { management }\end{array}$ & Examples & Interview quotes \\
\hline $\begin{array}{l}\text { Temporal practices } \\
\text { Controlling working time }\end{array}$ & $\begin{array}{l}\text { Reducing working time; finding } \\
\text { respite }\end{array}$ & $\begin{array}{l}\text { "I generally do not work at weekends. It is fairly sacred for } \\
\text { me." (Interview 3) }\end{array}$ \\
\hline Controlling living time & $\begin{array}{l}\text { Reducing leisure activities, such as } \\
\text { voluntary working }\end{array}$ & $\begin{array}{l}\text { "I restructured it bit by bit, so that I do no longer engage in } \\
\text { leisure activities which I had done earlier." (Interview 5) }\end{array}$ \\
\hline Managing clients & $\begin{array}{l}\text { Using appointments; blocking ap- } \\
\text { pointments with clients on several } \\
\text { days a week; selection of profitable } \\
\text { and effortless mandates; }\end{array}$ & $\begin{array}{l}\text { "Normally, the predominant number of clients come in for } \\
\text { pre-agreed appointments." (Interview 5) } \\
\text { "In case of very high workload, you somehow try to reject } \\
\text { smaller mandates which are less profitable." (Interview } 3 \text { ) }\end{array}$ \\
\hline Managing vacancies & $\begin{array}{l}\text { Reducing vacancies up to seven } \\
\text { days; replacement arrangements } \\
\text { with colleagues and staff }\end{array}$ & $\begin{array}{l}\text { "Due to my firm structure, I actually do not go on vacation } \\
\text { for longer than one week." (Interview 2) } \\
\text { "Well, I work together with a fixed law office for this pur- } \\
\text { pose, which I also replace during their vacation." } \\
\text { (Interview 4) }\end{array}$ \\
\hline $\begin{array}{l}\text { Spatial practices } \\
\text { Separating spaces }\end{array}$ & $\begin{array}{l}\text { Separate spaces for living and } \\
\text { working with different distance }\end{array}$ & $\begin{array}{l}\text { "I have also learned over time, that a spatial separation be- } \\
\text { tween home and work is extremely important." (Interview 4) } \\
\text { "Law firm [is located] in my house with separated rooms. In } \\
\text { fact, the law firm is a public area, the living rooms are thus } \\
\text { separated." (Interview 7) }\end{array}$ \\
\hline Practices of transition & $\begin{array}{l}\text { Acts and rituals of commuting be- } \\
\text { tween the living and working space, } \\
\text { such as walking with dog }\end{array}$ & $\begin{array}{l}\text { "And then we go early through the park and are there in } 20 \\
\text { minutes if we run extensively, i.e. we take a little detour. } \\
\text { When time is short, we are here in just } 10 \text { minutes." } \\
\text { (Interview 2) } \\
\text { "A typical work day begins by bringing our child to the } \\
\text { school bus." (Interview 5) }\end{array}$ \\
\hline $\begin{array}{l}\text { Behavioral practices } \\
\text { Controlling permeability } \\
\text { of boundaries between } \\
\text { work and non-work do- } \\
\text { mains }\end{array}$ & $\begin{array}{l}\text { Avoid taking work home; technical } \\
\text { equipment in offices solely; rules of } \\
\text { behavior for family members and } \\
\text { clients }\end{array}$ & $\begin{array}{l}\text { "It is also important to politely point out [to clients] that even } \\
\text { I have to finish work for the day at the evening." } \\
\text { (Interview 4) } \\
\text { "I am at home, I am there for my family and so I will not } \\
\text { start to take home any work." (Interview 5) } \\
\text { "Anyone who calls me for private matters without good } \\
\text { reason [at work] gets a telling-off." (Interview 11) }\end{array}$ \\
\hline $\begin{array}{l}\text { Employing assisting } \\
\text { staff }\end{array}$ & $\begin{array}{l}\text { One or more persons employed on } \\
\text { part- or full-time basis as office- } \\
\text { assistants }\end{array}$ & $\begin{array}{l}\text { "We have fixed office hours between } 8 \text { am and } 4 \text { pm, and } \\
\text { my employee is usually there." (Interview } 7 \text { ) } \\
\text { "[I have] three part-time employees [...] to facilitate my } \\
\text { work." (Interview 12) }\end{array}$ \\
\hline $\begin{array}{l}\text { Managing social } \\
\text { contacts }\end{array}$ & $\begin{array}{l}\text { Separating between private and } \\
\text { working contacts; tolerating of private } \\
\text { contacts becoming mandates, but } \\
\text { avoiding working contacts to become } \\
\text { private }\end{array}$ & $\begin{array}{l}\text { "I try to maintain a certain distance from my clients. There } \\
\text { are friends/acquaintances who become clients, but it is } \\
\text { much more rarely the case that clients also become } \\
\text { friends." (Interview 8) } \\
\text { "The fact is that my friends contact me [for work-related } \\
\text { topics], but that I hardly ever let clients enter my private } \\
\text { life." (Interview 3) }\end{array}$ \\
\hline $\begin{array}{l}\text { Emotional distancing } \\
\text { from clients }\end{array}$ & $\begin{array}{l}\text { Rejecting any invitations to dinner } \\
\text { or private events from clients }\end{array}$ & $\begin{array}{l}\text { "Sometimes it would be very beneficial to spend time with } \\
\text { having dinner with clients at weekends, [...] but I try to } \\
\text { maintain a certain distance." (Interview 12) } \\
\text { "It is also a matter of drawing boundaries, of not opening } \\
\text { itself up too far, but the latter is also a bit necessary." } \\
\text { (Interview 4) }\end{array}$ \\
\hline
\end{tabular}


the structure presented in Figure 1 - to subsume them to the main category "occupational requirements". Besides clients' expectations and family demands we handle occupational requirements as a main sub-field of institutional settings in case of selfemployed lawyers.

The analyzing procedures mentioned were computer-supported by the software MAXQDA. Since the interview material was in German, the categories used as well as relevant interview quotes were left in the original language. For this publication, the categories of analysis were re-translated into the English language since they were originally driven from English-language articles. Interview quotes used in the following were translated into English by the researchers and re-examined by the English editor.

\section{Results}

The studied group of self-employed German lawyers show different bundles of temporal, spatial and behavioral practices of boundary management (see Table 1). Our results reveal that the group considered is still constrained by numerous institutional settings which frame their boundary management in such a way that a discretional allocation of time, space or relevant social players by the persons interviewed is possible only to a limited extent. How boundary management practices of lawyers and institutional elements are interlinked, is the main focus of the following analysis. In order to examine these linkages, especially in terms of how self-employed lawyers respond to different institutional elements in their boundary work, we structure our results section according to the three institutional constituents - occupational requirements, clients' expectation and family demands, as summarized in Table 2.

\section{Boundary management in face of occupational requirements of lawyers}

One of the main components of occupational requirements is legal regulations of lawyers' activities. Given the existence of quite restrictive legal prescriptions in Germany regarding availability, vacation and professional training of lawyers, it could be expected that legal issues constrain boundary work of lawyers to a high degree. Our results show that especially the rule of replacement - as explained above - exerts a significant influence on temporal practices regarding vacation planning of lawyers. While prescribing explicit limits in case of absence from the job, the rule of replacement represents a clear institutional constraint on discretion in boundary management of lawyers. Our results show that the lawyers interviewed manage their work and non-work domains mainly in accordance with this prescription.

We can depict at least three strategies of boundary management in line with the rule of replacement: guaranteeing own availability, ensuring replacement, or taking work on to vacations. Interviewees remain in their absence from work at least available by telephone, in case of emergency some lawyers are ready to interrupt their vacations. For regular cases, lawyers assure their telephone accessibility by using answering machines, call diversions, an external telephone service or by engaging office assistants who control incoming calls and post. Some of the interviewees cooperate with another lawyer in order to be replaced. Taking work-related items (e.g. laptop) on vacation in awareness of only a limited opportunity for recovery in such a vacation period is 
Table 2: The linkages between boundary management between non-work and work realms and different institutional settings

\begin{tabular}{|c|c|c|c|}
\hline \multirow[b]{2}{*}{$\begin{array}{l}\text { Practices of } \\
\text { boundary man- } \\
\text { agement }\end{array}$} & \multicolumn{3}{|c|}{ Institutional elements } \\
\hline & Occupational requirements & Clients' expectations & Family demands \\
\hline $\begin{array}{l}\text {... in accordance } \\
\text { with institutional } \\
\text { requirements }\end{array}$ & $\begin{array}{l}\text { - Reducing vacancies up to } \\
\text { seven days } \\
\text { - Replacement arrangements } \\
\text { with colleagues } \\
\text { - Employing assisting staff }\end{array}$ & $\begin{array}{l}\text { - Offering flexible working } \\
\text { hours } \\
\text { - Guaranteeing availability } \\
\text { personally or via telephone, } \\
\text { also in the break time } \\
\text { - Using frame of reference of } \\
\text { emergency physicians } \\
\text { - Physical separation of } \\
\text { working and private space }\end{array}$ & $\begin{array}{l}\text { - Reducing working time in } \\
\text { favor of family demands } \\
\text { (e.g. young children), short } \\
\text { breaks or day off per week } \\
\text { - Reducing leisure activities } \\
\text { - Time segmentation, e.g. } \\
\text { fixed start and end of the } \\
\text { working day, spontaneous } \\
\text { vacancies } \\
\text { - Spatial segmentation of } \\
\text { working and private spaces } \\
\text { by avoid taking work home } \\
\text { and technical equipment of } \\
\text { offices solely }\end{array}$ \\
\hline $\begin{array}{l}\text {... resisting or ignor- } \\
\text { ing institutional } \\
\text { requirements }\end{array}$ & $\begin{array}{l}\text { - Taking vacancy few days } \\
\text { longer than allowed by the } \\
\text { rule without any replacement }\end{array}$ & $\begin{array}{l}\text { - Radical segmentation of } \\
\text { space and time by not } \\
\text { providing consultations in } \\
\text { private rooms and outside } \\
\text { of office hours } \\
\text { - Instructing family members } \\
\text { not to share private contact } \\
\text { information with external } \\
\text { persons } \\
\text { - Segmenting social } \\
\text { contacts; rejecting } \\
\text { invitations from clients } \\
\text { - Emotional distancing from } \\
\text { clients }\end{array}$ & $\begin{array}{l}\text { - Rules of ignoring private is- } \\
\text { sues, e.g. not answering } \\
\text { private calls during office } \\
\text { hours } \\
\text { - Educating family members } \\
\text { in social behavior towards } \\
\text { own working time and space }\end{array}$ \\
\hline $\begin{array}{l}\text {...negotiating insti- } \\
\text { tutional requirements }\end{array}$ & $\begin{array}{l}\text { - Informal agreements with } \\
\text { court } \\
\text { - Instrumental selection of } \\
\text { profitable and effortless } \\
\text { mandates } \\
\text { - Scheduling training courses } \\
\text { on weekend }\end{array}$ & & $\begin{array}{l}\text { - Tolerating private issues in } \\
\text { the working time and space }\end{array}$ \\
\hline
\end{tabular}

the next strategy of dealing with the prescription of availability. Even though the duration of annual leave taken by interviewees varies between few days to four weeks, most lawyers interviewed attempt not to take a period longer than seven days in accordance with the prescription. The interviewees legitimate their compliance to this rule also by indicating that in this way they avoid heavy workload which would cumulate during a long vacancy.

Cases of non-compliance with the rule of replacement are seldom mentioned. One person interviewed indicates that from time to time she ignores the prescription and takes vacations without ensuring accessibility or replacement. Then, however, her vacations exceed the prescribed period for only few days.

Legal prescription regarding professional training represents the second occupational requirement for lawyers. The interviewees consistently tend to source this issue into the non-working time by mainly scheduling training courses during the weekends 
in order to be available during the week and to guarantee downtimes to be as low as possible.

Together with legal requirements, the field of occupational specialization represents an additional institutional element framing boundary management practices. In some fields of legal activities such as civil law, lawyers are exposed to especially high external constrains because of fixed and short-term deadlines and frequent court hearings. In order to increase their discretion and temporal control of the work domain, the lawyers interviewed develop specific strategies, ranging from behavioral practices of organizing clients' appointments on fixed days in order to remain flexible on the remaining days up to informal agreements with judges not to arrange court hearings during their vacation periods, which illustrates how institutional constraints can be negotiated by the lawyers:

"If you inform your judge that you're out of office or on vacancy for a certain time period or you need a further extension of time in order not to have a deadline immediately after your vacancy then you'll get it. This is the advantage of doing business for a longer time judges show more consideration for you then." (Interview 4)

More discretion and negotiation than legal regulations allows dealing with socioeconomic issues of self-employment, the next aspect of occupation-based institutional settings of self-employed lawyers. In the most cases, the socio-economic constrains pave the way to self-exploitation of the self-employed. Even if working hours, according to our interviews, are about 40 hours per week on average, the real working time of the interviewees often exceeds the preferred working time due to economic constraints. Relieving working time and amount represents, thus, one of the dominant issue in the group studied. One of the strategies adopted by the lawyers in order to reduce working time is the instrumental selection of mandates. Before accepting a mandate, lawyers assess them regarding their item, effort required and profitability and reject mandates if they turn out to be less profitable. This applies especially to times of high workload.

The practice of employing additional staff, which is dominant among the persons interviewed, does not only have to do with legal requirements regarding availability in case of being out of office or on vacation but also with the reducing working time and amount. The number of assisting employees as well as the basis of their employment varies in the group studied between one person on a full-time basis up to three employees on a part-time or an hourly basis. By relieving lawyers from such administrative tasks as postal processing, appointment coordination, drafting written pleadings upon dictation or the preparation of charge calculations for clients, assisting employees are of high benefit. At the same time, they bear many risks, with personnel costs being the most important of them, as one interviewee points out:

"Sometimes I wish to have three secretaries [...] but I have to generate their income, they need paid time off, they can get sick as well and therefore the workload has to be very much higher." (Interview 10)

Lawyers who do not have any staff do not attribute this to their individual choice, but to economic reasons by pointing to the fact that the current volume of work as well as the income is not sufficient to bear further personnel costs. In face of these economic 
constraints resulting from the self-employment, work issues are often preferred and the non-work domain remains explicitly or latently marginalized.

One issue, which can be hardly marginalized, is individual sickness. Here, work and non-work domains intersect in such a way that the fragile status of boundary management in case of self-employed becomes particularly obvious. In case of sickness, the interviewees try to mobilize any possible mechanisms of boundary management, especially temporal and behavioral strategies, in order to limit eruptive consequences of the non-work domain for the work area of self-employed. The interviewed lawyers indicate that they either try to minimize sickness-induced downtimes or that they cover it by providing employees or colleagues as replacement or by working from home office. Even though, serious sickness represents a fearful scenario for the persons interviewed, since a longer sick leave in any case is perceived as problematic, because of the limited replacement by colleagues due to different fields and, even more problematic, because of financial shortages and the non-existing wages paid in case of sick leave for self-employers. It is thus not surprising that some individuals try to suppress this difficult topic by stating: "There is actually no sickness for lawyers" (Interview 6).

\section{Clients' expectations and boundary management}

Clients represent the second essential element of institutional setting in case of selfemployed lawyers. The requirements and expectations of clients lead to the preference of certain boundary work practices and require specific boundary management directly dealing with clients' expectations.

The availability to clients is one of the underlying principles of lawyers' work, not only required by legal regulations but also as a taken-for-granted normative expectation on the side of clients. The interviews indicate that lawyers show a wide conformity toward this expectation. The majority of interviewees adopt temporal strategies allowing high responsiveness towards their clients, while, for example, offering flexible office hours such as late in the evening or on weekends in order to respond to specific time demands of the clients as in the case of shift workers or assemblers.

Availability to clients is also an important issue concerning break arrangements of the working day. The break practices range from a fixed off-work break at a particular time or a flexibly movable break up to no break at all in case of high workload. Even though the interviewees use breaks for relaxation, meals or exchange with employees about non work-related topics, all of them basically remain available to their clients by telephone during their breaks.

Dealing with physical spaces of private and working life turns out to be the most important practice of boundary management with reference to clients' requirements in case of self-employed lawyers. There is remarkable agreement among the persons interviewed regarding their handling of the physical boundaries between both realms: all twelve participants of the study physically separate their private rooms and offices. Even if the physical distance between the rooms is different, ranging from few meters in cases where the office was arranged in the private house up to 30 kilometers with offices being rent in external buildings, respondents underlined the relevance of the physical separation of working and private spaces. Clients and their (supposed) wishes 
play a relevant role in the narratives provided by the interviewees by explaining the physical separation between private and working rooms. Physical separation of the spaces is assumed to be more acceptable among clients, with, for example, interviewee 10 saying that "this half and half thing didn't seem proper for the clients either", when remembering previous situations when the entrance to the private house and to the office used to be the same.

Separated rooms are also expected to prevent incidents when working issues intrude the private space and lead to remarkable tensions or frustrations on the side of the lawyers. In the interviews, numerous examples of such penetration of working issues into the non-work domain are indicated, like phone calls by clients at home, consulting family members and friends with legal questions in private rooms or working at home because of a high workload or forthcoming hearings. The level of experienced tensions in case of such an "intrusion" of working issues into the private sphere and the way of dealing with these moments is quite different and not without ambivalence. On the one hand, the lawyers apply the metaphor of emergency occupation as their frame of reference which makes the dogma of accessibility around the clock and the permeability of boundaries resulting from it sensible. Here, the intrusion of the working issues into the private space is considered as an integral part of the occupation and as an since unavoidable acceptable issue:

"It's like an emergency physician. He cannot leave the injured boy and say, I have to go to school tonight. No, these are just normal things." (Interview 4)

On the other hand, there are situations mentioned where boundary crossing is perceived by the lawyers as a literal threat for their private spaces. Illustrative cases for this are provided by lawyers living in a rural area where they are known to everyone and the clients sometimes "ringing the doorbell early Sunday morning" (Interview 4). As a result, the lawyers meet such intrusions by clients with rigid segmentation tactics, for example, by instructing family members not to provide mobile phone numbers to the residents of the village or denying any spontaneous consultations and instructing clients to visit them in their office hours and then not free of charge:

"They can simply make an appointment at this or that time, and I will be happy to answer the question against payment of the respective fee." (Interview 11)

From the perspective of lawyers, clients expect to save costs for consultancy when intruding their private space and getting informally consultation in a neighborly atmosphere. These practices of segmentation between work and non-work realms are linked to a serious dilemma of the self-employed lawyers: not to welcome such kind of unplanned interruptions of the private space without annoying real or potential client and jeopardizing the own income. Lawyers handle this dilemma by legitimizing their behavior to their clients while pointing to their personal liability in case of consultancy not in working rooms (and silencing boundary-saving as an argument):

"When someone calls and says I have a question, the bad thing is actually that you don't earn much money with this and it's often not only one question that is asked, and this information is to some extent subject to liability, too." (Interview 11)

This example demonstrates that boundary management practices in case of selfemployed lawyers are not only linked to the work and non-work-balance but are also interwoven with the socio-economic issues such as income-generation. 
Segmentation of social contacts represents an additional behavioral practice that can be obtained from interviews in reference to the clients' expectations. The lawyers tend to clearly differentiate their social contacts into work-related and their private contacts such as friends and family members. This boundary defined by the lawyers is permeable only in one direction: It is acceptable for the lawyers when private contacts enter the work domain in case of work-related questions and consequently become clients; the reverse case where clients enter the non-work domain and wish to become friends is tolerated much less willingly:

"The fact is that my friends contact me [for work-related topics], but that I hardly ever let clients enter my private life." (Interview 3)

The separation between "real-clients" and "friends-clients" is expressed in the issuing or non-issuing of an invoice by the lawyers for their services. Different to "real clients" who always get an invoice, mandates of family members are mostly carried out free of charge since they are regarded as belonging to the private domain.

Given these attempts of separation between private and work-related contacts, it is no surprise that the issue of emotional distance to the clients turns out to be one of the main social challenges as well as one of the main premises of the boundary management for lawyers. The persons interviewed are quite aware of the contradictory requirements of having a trustworthy relationship with the clients on the one hand and keeping emotional distance as required by the norm of professional service on the other hand. A rigorous emotional distancing from clients seems to be more challenging in some legal fields than in others, with family law being reported as a particularly challenging field in this regard. Lawyers use several practices allowing for this kind of professional balancing between the intimacy and emotional distance such as behavioral practice of rejecting any invitations from clients to dinner or events of private character. Even though they are aware of a potential income loss because of this, the lawyers adhere to the boundaries created and sacrifice part of the potential economic success in order to maintain them:

"Sometimes it would be very beneficial to spend time with having dinner with clients at weekends, [...] but I try to maintain a certain distance." (Interview 12)

\section{Family demands and boundary management}

The next element of institutional settings framing boundary management practices of self-employed lawyers are family-related issues. While family stands for the main institution representing the non-work domain of lawyers, demands resulting from family issues play a contradictory role for the boundary management practices. On the one hand, by requiring certain time and attention, family issues provide a balance to and relief from the work domain. On the other hand, family-related issues may lead to serious interruptions of work settings and rhythms, and may potentially induce additional work-related pressure instead of providing some respite from it.

As in any form of self-employment, child birth and parental leave of selfemployed lawyers represent a more or less acute challenge for the business in economic terms, thus, a challenging intersection between work and non-work domains. When dealing with parental leave, diverse arrangements were reported by interviewees, which represent different temporal practices of boundary management between 
work and family issues. The reduction of working time in favor of family issues is a behavioral practice of boundary management particularly used by self-employed lawyers with children. Besides part time working, the interviewees indicate the arrangements of short breaks as well as having one day off per week as the usual practices. The interviewees explicitly trace this back to the fact that they prefer family demands over their job requirements and accept considerably lower income or financial dependency from their spouses. In cases where lawyers with young children work fulltime, their partners normally make use of the parental leave for a period of up to several years.

The main strategy reported in the interviews in order to deal with family demands is time segmentation between work and non-work domains, here family issues. Interviewees indicate such behavioral practices as finding respite by deliberately dedicating time to family life, for instance in the form of off-work weekends with short trips with their families. Interviewed lawyers also use rules of a fixed start and end of the working day, mainly in correspondence with several rituals of transition, such as eating ceremonies with family, which provide a temporal corset for their working days:

"I have breakfast with my family [before work] [...] and that I am [...] at home for dinner; we have a fixed dinner time at 6pm.” (Interview 5)

Time segmentation is supported by practices of spatial separation. Having work rooms separated from private space, turns out as instrumental not only in case of dealing with clients' expectations as pointed out above but also as highly functional when dealing with family demands. When leaving their offices and going home lawyers consequentially avoid taking work with them in order to keep work domain away from home and family and to concentrate on family issues. Similar to time segregation, spatial separation is also accompanied by transitional rituals which bridge different physical spaces. These rituals of transition mainly vary between the commuting between private and working rooms by car or walking with the dog from the private room to the office in the morning and back in the evening.

In cases where temporal separation between the usual work and non-work time cannot be sustained, like working on weekends, the lawyers almost exclusively turn to their offices, no matter how distant they are from the private rooms. The reason for this separation of spaces is also the fact that the occupation-related equipment such as specialist literature, legal texts, fax machine, printer or legal software is located in the offices in order to hinder working in private spaces.

Despite these numerous segmentation practices and attempts to draw a line between work and non-work spaces, the interviews reveal numerous incidents where the spatial boundaries become highly permeable or are broken by family issues. There are different patterns of how private issues intrude the working space and how lawyers deal with these intersections of work and non-work domains. Instances of private life enter working spaces either as daily matters such as issues of private insurance, email contact with school teachers, doctor or coiffeur visits, or calls and visits by friends and family members in the office. One way of dealing with these issues is to marginalize private issues from the working space in a temporal sense by attending coiffeurs, teachers, doctors or insurance agents in the morning, before entering the offices, or in the lunch break, which is considered by the interviewees as a space of in-between 
work and non-work domains. By placing these events into the margins between the work and non-work spaces, the lawyers interviewed transform and mitigate the interrupting potential of these occurrences. The second form of dealing with private issues intruding the working space is their spontaneous integration by dealing with them immediately, like telephone calls from family members or booking of hotel rooms for holiday. Here, the intruding issues from non-work realm mainly serve as a welcome alternation from the work routine. Having the appropriate technical equipment in the offices such as printer, laptop and required software is the lawyers' main pragmatic reason for not moving these issues to the private spaces. The third way of dealing with private issues unexpectedly entering the working space is their radical segmentation and rejection. One such example is provided by interviewee 11 who reports about not tolerating phone calls from family members in her office, unless there are absolute emergency cases. As a rule she either does not respond to private calls made during her office hours or she asks her secretary to pre-select incoming calls. In order to make her rule visible, she instructs her family members "not to call without good reason".

Apart from the practices of segmentation mentioned above, there exist also arrangements indicating high integration between work and family issues. Especially cases where family members are employed by the lawyers provide a relevant foundation for such integrative boundary management, like in the case of a female interviewee employing her husband as an office assistant. This leads to a flexible intersection between working and non-working domains with any separation and segregation strategies becoming obsolete.

\section{Discussion: Institutionally framed boundary management of self-employed lawyers}

Self-employed lawyers show different bundles of practices which, in general, confirm existing empirical findings. Like in the case of previously studied occupations of selfemployed persons, the boundary work of lawyers ranges from managing time and space to the managing of persons and behavior in order to create and to maintain boundaries between work and non-work realms. Our study supports the findings of previous research where separating working and private spaces has been noted as one of the relevant tactics of boundary management among self-employed persons (Myrie \& Daly, 2009; Berke, 2003; Kreiner et al., 2009), even we are able to report few examples of integration of work and non-work realms. Attempts of segmentation range from practices of spatial separation of working space and spaces secured from work issues to the temporal and behavioral practices. Temporal tactics of controlling or reducing working time and finding respite used by the lawyers directly correspond with the findings of Kreiner et al. (2009). This fact suggests the applicability of the concepts on a broad scale of self-employed occupations. Additionally, self-employed lawyers make considerable efforts in order to thoroughly separate both domains by creating rules of behaving as well as limits of tolerable behavior and directly or indirectly communicating them to their clients, staff and family members. Work issues intruding into the non-work domain are only tolerated by the lawyers if they perceive them as emergencies or consider themselves in control of the situation. If this is not the case, 
lawyers gently or directly resist unexpected intrusions by clients into the private sphere in order to protect the boundaries defined.

Similar to Nippert-Eng (1996a), our results show that segmentation goes along with different transitional rituals bridging segmented spaces and time pieces between work and non-work domains, such as eating rituals or rituals of commuting. These transition rituals do not only act as facilitators of moving between domains (NippertEng, 1996a, p. 124), but also as daily reconfirmation of defined boundaries.

Additionally, the results of the present study confirm the importance of material objects for boundary definition and confirmation as convincingly demonstrated by Nippert-Eng (1996a), with technical equipment of the offices providing an illustrative example of an artifact which maintains physical boundaries between working and private realms.

In contrast to previous research on boundary management of self-employed persons, our results show that in case of self-employed lawyers in Germany individual boundary work cannot be properly understood without taking into consideration the institutional context. In our paper, we focus at three main constituents of institutional framework in case of self-employed lawyers: occupational requirements, including legal prescriptions and economic issues of self-employment, demands and expectations stemming from clients as well as requirements of the family or private life.

In reference to the workplace characteristics provided by Nippert-Eng (1994a), our results suggest that the institutional framework considered entails elements of "bureaucratic", "greedy" as well "discretionary" workplaces. Legal requirements considerably reduce the autonomy and discretion of self-employed lawyers in boundary work and functions as "bureaucratic" components. Socio-economic issues such as income insecurity coupled with availability-related expectations on the side of clients are prone to become "greedy" and to completely dominate over the private life of the self-employed lawyers. At the same time, the self-employment entails quite "discretionary" elements since it allows for high autonomy in boundary management by selecting only profitable mandates or reducing working hours in favor of time with family.

In contrast to the ideal types of workplaces according to Nippert-Eng (1996a), we consider the institutional context of self-employed German lawyers as a combination of all three dimensions which results in an institutional environment at the same time enabling and restricting individual discretion in boundary management. In face of the bundle of diverse institutional constituents the self-employed lawyers do not consider their workplaces as given and unchangeable but as permanently re-shapeable. Thus, boundary management of self-employed German lawyers consists of practices of compliance, resistance and negotiation in reference to different institutional elements.

The present study contributes to a deeper understanding of institutional settings which frame boundary management while empirically focusing on one specific occupational group, self-employed lawyers. Drawing on the study made by Piszczek and Berg (2014) the present study stresses the relevance of critical consideration of individualistic assumptions implicated by the boundary theory and supports institutionally informed research on boundary work. In empirical terms, the study contributes to the 
previous research on boundary work by delineating the complex bundle of institutional aspects which characterize the institutional framework surrounding work and nonwork domains in case of self-employed lawyers and including occupational requirements, clients' expectations and family demands. The findings show that separate elements of institutional settings and resulting boundary work of self-employed lawyers are interweaved with different tensions and contradictions, like managing clients in favor of own income vs. protecting the non-work domain without affronting mandates.

In conceptual terms, we contribute to previous research by linking practices of boundary management as used by lawyers with institutional elements and by showing that different institutional elements go along with diverse grades of individual discretion and exert different influence on boundary management. In addition to the model by Piszczek and Berg (2014), the present study focuses on an individual boundary work instead of organizational instruments and highlights the relevance of the occupational framework and the institutional settings resulting from the status of self-employment. We show that it is not only the existence and the coverage of legal regulations, as stated by Piszcek and Berg (2014), that are of interest for understanding the linkage between institutional context and boundary work, but that normative expectations and demands stemming from the stakeholders (i.e. clients in case of self-employed persons) and family members should also be taken into account.

In order to describe and to classify boundary work of self-employed lawyers in an institutionally informed way new analytical categories are required which go beyond the individual-oriented duality of segmentation and integration as suggested by the boundary theory. In the present study, we propose categories of "complying", "resisting" and "negotiating" as those which, in our view, are suited to indicate the linkages between individual boundary management and institutional settings.

The limitations of the study should also be taken into account. The main methodological shortcoming of the work is the limited representativeness of the results. Since self-employed lawyers represent a highly heterogeneous occupation with numerous different fields of specializations, the results gained from twelve interviews represent only a small group of self-employed lawyers in Germany. Additionally, because of relatively high institutionalization degree of this occupational group as could be seen from the number of legal constrains and prescriptions, the empirical results obtained in this study can be barely transferred to other occupational groups. However, at least partial generalization is possible, since there is high correspondence with boundary work practices reported by previous studies focusing on completely different occupational groups, which point to the fact that there are certain commonalities of boundary work among self-employed persons of any occupation.

Our study suggests numerous prospects for future research in boundary work. First, in our view, not only practices of boundary management but also the structure of institutional context deserves explicit attention in order to explain why certain practices of boundary work exist or dominate. Second, further empirical investigations comparing different occupational groups or different employment forms - employed, self-employed, unemployed - are needed in order to broaden our understanding of how institutional frames affect individual boundary work practices. Third, while considering institutional settings of boundary management as well as tensions-evoking in- 
fluence of institutional elements should be taken into account more thoroughly than it could be done in the present study. A further in-depth analysis into the way institutional elements constrain or enable certain kind of boundary management represents an important issue of institutionally based boundary work research.

\section{References}

ARGE Anwältinnen im DAV (Ed.) (2012). Anwältin und Mutter - klar geht das! vierC print: Berlin.

Ashforth, B.E., Kreiner, G.E., \& Fugate, M. (2000). All in a day's work: Boundaries and micro role transitions. Academy of Management Review 25(3), 472-491.

Berke, D.L. (2003). Coming home again: The challenges and rewards of home-based self-employment. Journal of family Issues, 24, 513-546.

Busse, F. (2010). Deutsche Anwälte. Geschicbte der deutschen Anwaltschaft 1945-2009. Entwicklungen in West und Ost. Bonn: Deutscher Anwaltverlag.

Clark, S.C. (2000). Work/family border theory: A new theory of work/family balance. Human Relations 53(6), 747-770.

Code of Civil Procedure as promulgated on 5 December 2005 (Bundesgesetzblatt (BGBl., Federal Law Gazette) I page 3202; 2006 I page 431; 2007 I page 1781), last amended by Article 1 of the Act dated 10 October 2013 (Federal Law Gazette I page 3786) (Zivilprozessordnung (ZPO) in der Fassung der Bekanntmachung vom 5. Dezember 2005 (BGBl. I S. 3202; 2006 I S. 431; 2007 I S. 1781), die durch Artikel 1 des Gesetzes vom 10. Oktober 2013 (BGBl. I S. 3786) geändert worden ist.)

Eggert, K. (2013). STAR: Umsatz- und Einkommensentwicklung der Rechtsanwälte 1993-2010. BRAKMitteilungen, 4, 154-159.

Fachanwaltsordnung (FAO) in der Fassung vom 1.1.2011 (2011). Retrieved 01.11.2013, from http://www.brak.de/w/files/02_fuer_anwaelte/berufsrecht/fao-stand-01.01.11.pdf.

Heussen, B. (2009). Wie geht der gute Anwalt mit dem Honorar bei dem Mandanten um? Anwaltsblatt, 59(3), 157-163.

Hommerich, C. (2009). Die Freien Berufe und das Vertrauen in der Gesellschaft. Baden-Baden: Nomos.

Hommerich, C. (2001). Der Einstieg in den Anwaltsberuf. Eine empirische Untersuchung der beruflichen Situation von Rechtsanwältinnen und Rechtsanwälten. Bonn: Deutscher Anwaltverlag.

Hommerich, C. (1988). Die Anwaltschaft unter Expansionsdruck. Eine Analyse der Berufssituation junger Rechtsanwältinnen und Rechtsanwälte. Essen: Deutscher Anwaltverlag.

Hommerich, C., \& Kilian, M. (2009). Einzelanwälte - die schweigende Mehrheit. Anwaltsblatt, 59(4), 298.

Hommerich, C., Kilian, M., \& Dreske, R. (2008). Statistisches Jabrbuch der Anwaltschaft 2007-2008. Bonn: Deutscher Anwaltsverlag.

Kilian, M. (2011). Die Vergütung des Rechtsanwalts. In Deutscher Anwaltverein (ed.), Anwälte und ibre Geschichte (pp. 701-740). Tübingen: Mohr Siebeck.

Koch, L., \& Kilian, M. (2007). Anwaltliches Berufsrecbt. München: C.H. Beck.

Kreiner, G.E, Hollensbe, E., \& Sheep, M.L. (2009). Balancing borders and bridges: Negotiating the workhome interface via boundary work tactics. Academy of Management Journal, 52(4), 704-730.

Kreiner, G.E., Hollensbe, E.C., \& Sheep, M.L. (2006). Where is the 'me' among the 'we'? Identity work and the search for optimal balance. Academy of Management Journal, 49(5), 1031-1057.

Lührig, N. (2013). Das Ende des Dogmas der Verfügbarkeit. Anwaltsblatt, 63(4), 265-267.

Mayring, P. (2010). Qualitative Analyse. Grundlagen und Techniken. Weinheim \& Basel: Beltz.

Myrie, J., \& Daly, K. (2009). The use of boundaries by self-employed, home-based workers to manage work and family: A qualitative study in Canada. Journal of Family \& Economic Issues, 30, 386-398.

Nippert-Eng, C.E. (1996a). Home and work. Negotiating boundaries through everyday life. Chicago: University of Chicago Press.

Nippert-Eng, C.E. (1996b). Calendars and keys: The classification of „Home“ and „Work“. Sociological Forum, 11(3), 563-582. 
North, D. (1990): Institutions, institutional change and economic performance. Cambridge: Cambridge University Press.

Oberlander, W. (2008). Der Einzelanwalt - eine bedrohte Art? WIR, 3, 76-78.

Oberlander, W., Eggert, K., Nafts, V., \& Kreider, I. (2010a). Berufseinstieg und Berufserfolg junger Rechtsanwältinnen und Rechtsanwälte 2010. Ergebnisse der Folgestudie im Auftrag der Selbsthilfe Rechtsanwälte e.V. Schriftenreibe des Instituts für Freie Berufe an der Friedrich-Alexander-Universität Erlangen-Nürnberg, 37. Nürnberg: IFB.

Oberlander, W., Eggert, K., \& Kreider, I. (2010b). Der Wandel im anwaltlichen Berufsbild. Eine empirische Untersuchung im Auftrag der Selbsthilfe der Rechtsanwälte. Schriftenreibe des Instituts für Freie Berufe an der Friedrich-Alexander-Universität Erlangen-Nürnberg, 34. Nürnberg: IFB.

Piszczek, M.M., \& Berg, P. (2014). Expanding the boundaries of boundary theory: Regulative institutions and work-family role management. Human Relations, 67(12), 1491-1512.

Prossliner, S. (2009). Was ist die Erziehung von Kindern wert? Anwaltsblatt, 59(3), 212-213.

Remmertz, F.R. (1996). Anwaltschaft zwischen Tradition und Wettbewerb: das Berufs- und Standesrecht der Rechtsanwälte in England und Deutschland. Schriftenreihe des Instituts für Anwaltsrecht an der Universität zu Köln, 21. Bonn: Deutscher Anwaltverlag.

Römermann, V., \& Hartung, W. (2002). Anwaltliches Berufsrecht: Ein Lebrbuch. München: C.H. Beck.

Rybnikova, I., Krätzel, C., \& Schmidt, M. (2012). Arbeit und Leben im Einklang. Was tun Freiberufler für ihre Work-Life-Balance? Zeitschrift Führung und Organisation, 81(6), 386-390.

The Federal Lawyers' Act (Bundesrechtsanwaltsordnung- BRAO). Last amended by Art. 8 G v. 6.12.2011 I 2515.

Wendt, P. (2012). Die Fachanwaltsordnung in der Praxis. Anwaltsblatt, 62(2), 110-113. 